\title{
Boulevard to broken dreams, Part 2: Implementation of the Polonoroeste road project in the Brazilian Amazon, and the World Bank's response to the gathering storm
}

\author{
A implementação do projeto de Estrada Polonoroeste \\ na Amazônia brasileira, e a resposta \\ do Banco Mundial à avaliação negativa
}

ROBERT H. WADE*

RESUMO: Esta é a segunda parte do ensaio sobre as circunstâncias que levaram o Banco Mundial a adotar normas e políticas operacionais para a proteção ambiental e dos povos indígenas no final de 1980, tal como foi traçado pela turbulenta história do projeto rodoviário Polonoroeste na Amazônia brasileira. Polonoroeste se tornou a ponta de lança onde as ONGs ambientais fizeram seu primeiro ataque ao banco por participar da destruição, em grande escala, ambiental e dos povos indígenas.

PALAVRAS-CHAVE: normas de política; florestas tropicais; povos indígenas; Banco Mundial; ONGs ambientais; Governo do Brasil; Congresso dos EUA; Projeto Indonésio de Transmigração.

ABSTRACT: This is the second part of the essay on the circumstances that led the World Bank to embrace norms and operational policies for environmental and indigenous people's protection in the late 1980s, as traced through the turbulent history of the Polonoroeste road project in the Brazilian Amazon. Polonoroeste became the spearhead with which environmental NGOs made their first attack on the Bank for participating in large-scale environmental and indigenous peoples' destruction.

KEYWORDS: policy norms; rainforests; indigenous peoples; World Bank; environmental NGOs; government of Brazil; US Congress; Indonesian Transmigration Project.

JEL Classification: Q5; O13; I3.

\footnotetext{
* Robert H. Wade is professor of political economy at the London School of Economics. E-mail: R. Wade@lse.ac.uk. Submitted: 13/February/2015; Approved: 17/April/2015.
} 
This is the second part of the essay on the circumstances that led the World Bank to embrace norms and operational policies for environmental and indigenous people's protection in the late 1980s, as traced through the turbulent history of the Polonoroeste road project in the Brazilian Amazon. Polonoroeste became the spearhead with which environmental NGOs made their first attack on the Bank for participating in large-scale environmental and indigenous peoples' destruction.

Part 1, published in issue 36 (1), traced the history from the Bank's first mission up to the Board of Executive Directors' approval of the project in 1981. It finished with an account of how the Board of Executive Directors came to approve the first phase of the project. The regional project staff ensured that the Board was not presented with most of the warnings from the Bank's central technical experts. Those Executive Directors who had learned of the warnings more informally kept silent at the Board meeting because the Executive Director for Brazil supported the project. Part 2 describes what happened on the ground as the project began to be implemented; and what happened inside the Bank as some of the central experts reached outside the Bank secretly to recruit NGOs to apply pressure from the outside, both directly and indirectly through the US executive and Congress (which had to approve US financial contributions to the Bank). In this respect, too, Polonoroeste was a milestone, because reaching out for external allies had not happened before. The Bank's later establishment of a serious environmental and indigenous peoples' capacity owed a lot to the Polonoroeste campaign.

What happened in Polonoroeste is not just of historical interest. The results on the ground prefigured the results of later road projects into the Amazon; and prefigure likely results of today's Avança Brazil program to build multiple highways, dams, power lines and other infrastructure throughout the Amazon, including close to nature reserves and rare ecosystems.

The first part of this essay on the Polonoroeste project, published in issue 36 (1), traced the history from the Bank's first reconnaissance mission up to the Board of Executive Directors' approval of the project in 1981. It showed how the project became controversial within the Bank long before it came to the attention of outside critics (which runs contrary to general belief that it became controversial because of external NGO pressure). The fight was mainly between, on the one hand, the project staff in the Latin American vice presidency, who saw themselves as innovating a whole new and sustainable approach to development in rainforest areas and who also had a distinct career incentive to get the loans approved, and on the other, technical experts in the central, advisory part of the Bank, who thought that the project plans had little chance of being implemented and who had no such career incentives vested in approval of particular projects. The techni- 
cal experts saw themselves as having to relate to the regional projects staff sometimes as diplomats and sometimes as guerrillas as they tried to ensure good project quality.

Part 1 finished with an account of why the Board of Executive Directors approved the first phase of the project. The regional project staff ensured that the Board was not presented with most of the warnings from the central experts. Those Executive Directors who had learned of the warnings more informally kept silent at the Board meeting because the Executive Director for Brazil supported the project.

Part 2 describes what happened on the ground as the project began to be implemented; and what happened inside the Bank as some of the central technical experts reached outside the Bank secretly to enlist NGOs to bring external pressure, both directly and indirectly through the US executive and Congress (which had to approve US financial contributions to the Bank). In this respect, too, Polonoroeste was a milestone, for reaching out for external allies had not happened before. The Bank's later establishment of a serious environmental and indigenous peoples' capacity owed a lot to the Polonoroeste campaign.

What happened in Polonoroeste is not just of historical interest. The results on the ground - notwithstanding all the Bank's fine plans for safeguards - prefigured the results of later road projects into the Amazon; and they prefigure likely results of today's Avança Brazil program to build multiple highways, dams, power lines and other infrastructure throughout the Amazon, including close to nature reserves and rare ecosystems.

\section{PERFORMANCE ON THE GROUND}

The project champions justified the project, before it began to be implemented, in terms of the disorders it would help to avoid. Ironically, their picture of what it would help to avoid turned out to be reasonably accurate descriptions of what did happen as the result of its partial implementation. The road works raced ahead, the paving being completed within three years. Everything else lagged far behind and was often contentious. With the bulk of the funds disbursed for the road the Bank then had relatively little leverage left for getting the other things done. (The Amerindian component was financed entirely by Brazil, at the Brazilians' insistence.)

The highway and the Bank's endorsement of the whole project contributed to a flood of migrants. A "golden west" fever took hold. Population in the project- 
affected area surged from an estimated 620,000 in 1982 to 1.6 million in $1988 .{ }^{1}$ The assumptions on which the Polonoroeste development strategy had been based turned out to be wildly inaccurate, and the performance indicators veered far from their expected path. Remarkably, the Bank had not make estimates of the effects of the highway on migration, nor had it worked out alternative scenarios based on different migration assumptions.

The concerned government agencies proved largely unable or unwilling to implement what the government had agreed with the Bank they would do. Neither the territorial government nor the federal government did much to finalize the legal processes delimiting and enforcing the boundaries of the Amerindian and ecological reserves, or to limit the logging, or to provide the credit and the agricultural extension necessary to make the settlements viable. Deforestation and spontaneous settlements occurred outside the demarcated areas, helped by the feeder roads. "In Rondonia there is not even a parody of forest management", reported a forester consultant to the Bank in $1985 .^{2}$ The newly created state of Rondônia created a military forest battalion, which for a long time lacked most of what they needed to do their job - from boots, to arms, ammunition and transport.

The forestry agency was not even able to count the logs coming out, let alone check the logging. Logging trucks came to be known as "ants" in testimony to their numbers and incessant activity. The Amerindian protection agency proved not only ineffectual but even contemptuous of Amerindians at its top levels. In the sites of new colonization settlements the land agency got the sequence of soil surveys and settlement exactly wrong: first it settled the people, then it began to do (limited) soil surveys.

Brazil's fiscal crisis and over 100 percent inflation wrought havoc with implementation planning. The fiscal crisis meant that government agencies did not receive their operating budgets until half way through the year, which meant in the Amazon not until the start of the rainy season. But much of the project work had to be done in the dry season, and so was delayed until the rains passed. By then the budget allocation had lost much of its purchasing power.

The problem was especially serious in the health component: virtually nowhere in the whole vast project area did the three necessary ingredients all exist

\footnotetext{
${ }^{1}$ World Bank, "World Bank Approaches to the Environment in Brazil”, vol. V, p. 59.

${ }^{2}$ Marc Dourojeanni, "An example of the complexity of the development in the humid tropics: The Northwest Region Development Program in Brazil”, 1985, cited in Graham Searle, Major World Bank Projects: Their Impact on People, Society and the Environment (Camelford, Cornwall: Wadebridge Ecological Centre, 1987), p. 99.
} 
together: a health clinic; a trained and reliably salaried person; and essential supplies. Political bosses used their control of one or other of the ingredients to win political support. Malaria raged like a monster out of control. Many thousands died.

On one of her visits a member of the Bank's project team, Maritta KochWeser, asked to see a health center shown in the project accounts to have been finished. She was taken to the spot and shown... a rotting pile of timber. Project officials explained that by the time they received authorization to spend the budgeted funds the money had been substantially devalued by inflation, and then the rainy season began; by the next dry season the money would pay for no more than the wood. This is what Koch-Weser referred to as the "one legged cow" problem; the budgeted amounts, given these financial conditions, would suffice only for making the equivalent of one legged cows.

There were unanticipated legal problems too (the project missions had not included a legal expert). Several of the ecological and Amerindian reserves, once demarcated, had uncertain legal validity, because there were counterclaims to the same land and Brazilian law had no way to reconcile the competing claims.

The highway and feeder roads opened the area not only to the intended beneficiaries, small farmers, but also to (often highly capitalized and armed) loggers, miners, and cattle ranchers, who received large state subsidies, while the small farmers got none. The loggers, miners and ranchers had been more or less ignored in the planning, for the program was seen as one for "small farmers", even though it was also billed as an integrated regional development program. The activities of these extractors formed a flourishing extractive economy. ${ }^{3}$

The combination of poor soils, lack of farming skills, and lack of farm services induced many small farmer "project beneficiaries" to join the extractive (logging, mining, ranching) economy. Not till 1986 did FAO experts do the calculations that explained what had been happening on the ground: they showed that a settler who cleared a plot of jungle and worked it for the three years necessary to claim possession could get much higher returns by selling the property to a (subsidized) speculator and then moving on to clear another plot than by opting for sustained cultivation. Also, poor farmers, once settled, quickly repeated the only pattern they knew from latifundio in other parts of the country - they em-

\footnotetext{
${ }^{3}$ Cattle ranching can be included as extractive because the conversion of tropical rainforest to pasture "rates the worst, environmentally, of all conceivable alternatives". Robert Goodland, "Environmental ranking of Amazonian development projects in Brazil”, Environmental Conservation, vol. 7, n. 1, spring, 1980, pp. 18-19.
} 
ployed landless share croppers to work their newly titled land, creating a new underclass even poorer than themselves.

Underlying many implementation problems was the "carpet bagging" nature of frontier society (in the North American metaphor), with predatory elites able to suborn the local offices of government agencies. ${ }^{4}$ Almost everyone who benefited from the extractive economy in the region was opposed to the ecological and Amerindian components; and by the implementation stage of Polonoroeste, the extractive economy began to swamp the agricultural economy under the impact of new mining discoveries. Even had there been more political support, it would still have been difficult to strengthen implementing capacity on the ground given the fiscal crisis and high inflation, and given, most importantly, the flood of migrants that the highway upgrading helped to bring.

In retrospect the outcome could hardly have been different, for all the innovative plans that were made about where the forest and Amerindian reserves should go and about what sort of crop patterns the new settlers should practice. It was not just that the Bank and Brazil had little data on such fundamentals as soils, as the specialists in the Bank's Agriculture and Rural Development Department kept saying. It was, more basically, that the Bank hardly engaged with the question of the ability and willingness of the government agencies on the ground to do what the plans required them to do.

\section{FEEDBACK AND RESPONSE}

Everyone in the Bank recognized that the project would have to be carefully supervised. During loan negotiations the Bank insisted that a non-governmental Brazilian agency be given the task of evaluating information about progress on the ground, a step the Brazilian side resisted. Eventually, under Bank pressure, it appointed a little known university-based consulting group with no environmental expertise. When the Bank pressed for environmental expertise the consulting group linked up with a marine and oceanographic institute. When the Bank pressed again a year went by before the consulting group found an organization with green expertise. A Bank report, examining the Bank's world-wide monitoring and evaluation efforts, commented about Polonoroeste, “project management [on the Brazilian side] at times tried all its tools - vetoing access to information, claiming that evaluations were not carried out to the letter of the contract or competently, or

\footnotetext{
${ }^{4}$ Margaret Keck, "Planafloro in Rondonia, Brazil: the limits of leverage", in Jonathan Fox and David Brown (eds.), The Struggle for Accountability: The World Bank, NGOs, and Grassroots Movements, Boston: MIT Press, 1998.
} 
not releasing travel funds or salaries [...] to make sure the process was as difficult as possible". ${ }^{5}$

The Bank, too, was slow to acknowledge, accept and act upon the information in internal reports and those of the external evaluating agency. ${ }^{6}$ In the whole of 1984, for example, there was only one supervision mission, involving 13 staff weeks. ${ }^{7}$ No Bank staff were stationed near the region. Hardly surprising that the Brazilians concluded that the Bank was not entirely committed to the non-road building objectives of the project.

Nevertheless, the growing imbalance between the road work and the rest of the project became well-known to the project staff. Yet notwithstanding the Brazilians' failure to meet core conditions and in disregard of the terms of the loan agreement, the Board approved the phase III loan for Polonoroeste in October 1983 for the purpose of creating new agricultural settlements. ${ }^{8}$ In their presentation of the phase III project to the Board the Latin America region's staff made no reference to the difficulties being encountered on the ground. The staff said, "This project built upon and extended to new settlement areas the strategy of development used in the prior phases, which were being implemented in line with forecasts". They assured the Board that the projects had been designed to provide services and credit to small farmers, but did not say what they already knew, that credit and services were not arriving and that farmers were indeed selling out and moving closer to the frontier or into the cities and towns.

On the special project for the protection of Amerindian communities the staff said, "The Bank had monitored the progress of this special project closely and would continue to do so"- without saying what the results of its "close monitoring" had revealed, other than, "the Bank would not have gone ahead with any project in the region if it had not been convinced that the Government was implementing the Amerindian component to its fullest capacity". All this was designed to mislead by enough to get Board approval for the final phase.

By this time, two years after they had approved phase I, some Executive Directors were beginning to worry about Polonoroeste. To each of their concerns the

\footnotetext{
${ }^{5}$ World Bank, "An Overview of Monitoring and Evaluation in the World Bank”, Operations Evaluation Department Report No. 13247, June 30, 1994, p. 31.

${ }^{6}$ See World Bank, “World Bank Approaches to the Environment in Brazil”, vol. V, p. 94.

${ }^{7}$ World Bank, "World Bank Approaches to the Environment in Brazil”, vol. V, p. 94. However, members of the core team say that they piggy-backed supervision work on top of project preparation work for later projects in the three phase package, so that actual supervision was more than the "supervision" figures show.

${ }^{8}$ Phase II had been for the extension of phase I into the next-door state of Mato Grosso.
} 
staff gave reassuring replies that concealed much contrary information. ${ }^{9}$ The staff misled not only the Board but also the president. In a briefing paper on Polonoroeste to President Clausen in December 1983, ${ }^{10}$ the staff wrote, "The Bank maintains the right to supervise the Special Project [for Amerindian protection] and no obstacles in this respect have been encountered. Bank staff contact with FUNAI is easy [...] Implementation of the Special Project is now satisfactory [...] We have, and will continue to monitor the Special Project closely given its sensitivity and visibility in the international scene."

This is another example of an outright lie, designed to keep the disbursement of the loan on track (the key criterion of success for the project staff and their managers). The internal files show that at this time the division chief was telling the Brazilian government that implementation was very unsatisfactory. ${ }^{11}$ Few of the 37 Indian reserves had been completely demarcated and registered, and at least 15 had recently been invaded by squatters, loggers, and others. In other words, the staff's internal reports after field visits and what they reported up the line to senior management differed substantially. Those with managerial responsibility for the project portrayed things in the best light, not least because senior managers let it be known they did not want to hear bad news.

\section{SUSPENSION OF DISBURSEMENTS}

After the slow start in establishing a competent "independent" evaluation agency, evaluation teams belonging to "Fundação Instituto de Pesquisas Econômicas (FIPE) of the University of São Paulo brought together experts in malaria, indigenous peoples and rural development, and spent some six weeks every year in the field collecting data. By their second year they produced damning results based on thorough ground-level knowledge. They fed these results to the project staff at the Bank, reinforcing a growing conviction that only suspension of disbursements might produce a stronger commitment on the part of the agencies in the project area.

The mid-term review mission, of nine members (led by a person not previously involved in the project team), went out in November 1984 and presented its

\footnotetext{
${ }^{9}$ Minutes of meeting of the Executive Directors, October 25, 1983, dated December 15, 1983.

${ }^{10}$ Briefing paper to A.W. Clausen from Suitbertus van der Meer (acting regional VP) through Ernest Stern, "Brazil- Northwest Region Integrated Development Program-- Briefing on Amerindians", dated Dec 28, 1983, emphasis added.

${ }^{11}$ For example, telegram from Hendrick van der Heijden to Minister Mario Andreazza, Ministry of Interior, dated 17 March 1983. van der Heijden replaced Skillings as division chief for Brazil Programs.
} 
report in late February 1985. By now, Skillings was gone, several new people had joined the team, lots of accurate feedback was on hand. In these new circumstances the mission's report was able to document the many failings. ${ }^{12}$ It said that the whole program's "mitigating” measures had been "stunted by weak program coordination, institutional inefficiencies and an undisguised lack of political support for environmental and Amerindian protection".

The whole Northwest program had arrived at a critical juncture, the mid-term review concluded. If the program were "to stem [the] adverse and growing trend towards transgressions into reserve lands and failures in small-farmer colonization" it needed to be strengthened with "far more effective coordination and implementation instruments". It laid out an action plan to which the Brazilians would have to commit themselves in order for disbursements to be resumed. It concluded, "The above proposals [...] are made with the firm belief that past Bank involvement in the Northwest program has, overall, helped to prevent even worse outcomes, and that, however unrewarding and thankless the defense of the small farmers, Indians and environment of the region may be, the Bank should do its utmost to help overcome the present difficulties and remain involved in the orderly development of the Amazon". ${ }^{13}$

Soon after the mid term review was presented, in March 1985, the senior regional managers decided to suspend disbursements until such time as a "Corrective Action Program” could be agreed on and specific measures taken for Amerindian protection. Suspension of disbursements was a rare event. In this case it owed much to the fact that by the start of 1985 a completely new line of command on Polonoroeste was in place, comprising people who had no special interest in the project because not involved in its initiation. It included a new project officer (Maritta Koch-Weser), who had been responsible for "social” aspects of the project since 1981 and who was now given responsibility for the whole. (Recall that until this time no one had responsibility for substantive integration of all the components, with the partial exception of Skillings in the early years.) The new line of command also included a new deputy division chief and new division chief for Brazil Projects; a new division chief for Brazil Programs, who considered Polonoroeste an embarrassing nuisance he did not wish to deal with; and a new vice president for Latin America.

With this change of personnel Maritta Koch-Weser, who had long concluded

\footnotetext{
${ }^{12}$ Mid-term review, internal memorandum of February 25, 1985.

${ }^{13}$ World Bank, "World Bank Approaches to the Environment in Brazil”, vol. V, p. 75.
} 
that only suspension might get the Brazilians to take their commitments seriously, was able to act.

Then came two changes in the larger context. First, the NGO campaign against what was billed as the Polonoroeste "debacle" began, as a few Bank staff linked up with NGOs like the Environmental Defense Fund and supplied them with information. (They smuggled one of the NGO leaders past the Bank's security guards night after night to trawl through documents.) The NGOs called for suspension of disbursements, and powerful figures in the US Congress called for the US to cut its contributions to the Bank. Second, Brazil's first civilian government in twenty years had just taken office, and could accept a suspension as indicting its military predecessors rather than itself.

Five months later, in August 1985, when the Brazilian government presented to the Bank an action plan to deal with the problems and showed evidence that the settlers had been removed from a recently invaded Indian reserve, the Bank resumed disbursements.

\section{AFTER 1985}

Maritta Koch-Weser, project officer from early 1985, was moved off Polonoroeste after two years in 1987 on the arrival of a new director of the Brazil Department. ${ }^{14}$ The new director couldn't understand all the fuss about Indian protection, he said. "They wear T shirts and sneakers just like everyone else". He openly disparaged her work on Amerindian protection. "It's bullshit", they heard him say. He appointed a new project officer, one of whose first moves was to agree to the Brazilian government's request to terminate the contract with the university-based monitoring and evaluation unit. ${ }^{15}$ The new project officer found it inconvenient to have such a unit connected to the project, now that it had finally begun to produce some critical reports. In any case, he was a general economist more interested in agricultural production than in social and environmental issues; and as son of a Uruguayan cattle rancher he did not hide his belief that absorption of Indians into the national culture, and cattle ranching in place of rainforest, were both signs of progress which the Bank should encourage.

Suspension did have an effect. In the period from 1985 to the formal end of the Polonoroeste project in 1989, the Brazilian government somewhat strengthened the implementing capacities of the state agencies, demarcated most of the

\footnotetext{
${ }^{14}$ Armiene Choksi.

${ }^{15}$ Luis Coirolo.
} 
reserves, and provided some of the infrastructure of the settlement projects (the health centers, water supply systems, schools, storage facilities). Gradually the government on the ground began to make some progress in doing some of the things it had agreed to do years before.

Yet the study by the Bank's Operations Evaluation Department found that "despite the government's formal compliance with most of the recommendations made by the Bank at the time of the mid-term review [late 1984/early 1985], in general the situation in September-October 1989 was not very different from that encountered in late 1984. Polonoroeste appears to have been largely unable to implement and/or sustain many of its environmental protection measures or to avoid the continual invasion of reserve areas by loggers, prospectors, and spontaneous settlers". ${ }^{16}$ The project organization on the ground could not even maintain the toilets in the headquarters' building -"the filthiest toilets I'd ever seen in my life", said one much-traveled FAO agricultural expert who visited in 1986.

In the words of an FAO agricultural expert, "We failed to grasp the nettle of institutional problems, we failed to recognize that we were dealing with a lot of rascals. All segments of Polonoroeste planning gave insufficient weight to the hidden agendas of almost everyone with whom we were dealing. They were almost universally motivated by what they could make in the short term in a turbulent situation. Then we grossly over-estimated the capacity of Bank leverage to alter this." 17

Skillings himself rested his decision to go ahead on the conviction that the governor of Rondônia "had his heart in the right place" - that he was genuinely concerned to alleviate the poverty of the settlers, as indicated by his commitment to upgrade slums during his tenure as mayor of a regional city. ${ }^{18}$ Confidence in the commitment of the governor translated - quite wrongly - into confidence in the ability of the government apparatus to deliver its commitments. The division of labor between the Bank and FAO did not help; the FAO experts thought it was the Bank's responsibility to worry about the institutional problems, while the Bank was happy to assume that FAO had taken care of the problem of securing the agreement of government agencies to provide the requisite package of agricultural support.

\footnotetext{
${ }^{16}$ World Bank, "World Bank Approaches to the Environment in Brazil”, vol. V, p. 108. For more on the wider political context of Amazonian destruction, see Andrew Hurrell, "Brazil and the international politics of Amazonian destruction", in The International Politics of the Environment, A. Hurrell and B. Kingsbury (eds.), Oxford: Clarendon Press, 1992.

${ }^{17}$ Simon Hocombe, personal communication, 20 June 1997.

${ }^{18}$ Robert Skillings, interview with author, 24 June 1996.
} 
In short, the Bank's desire to lend to Brazil and at the same time show the world how to do rainforest settlement, coupled with its general avoidance of political or administrative analysis, led the relevant people to assumptions about Polonoroeste that the new Latin American vice president described, looking back, as "almost deliberately naive". ${ }^{19}$ In particular, they simply assumed that the Brazilians would respond to Bank pressure, and that agreements reached at the apex of national agencies in Brasilia could be carried out against the wishes of elites in the far periphery. They also assumed that the senior managers of the Bank had more than a passing interest in the substance of the project, as distinct from moving money out the door.

Throughout, the clinching legitimation for Bank involvement was that without the Bank the project would have gone ahead anyway, with much worse results. This in turn hinged on the assumption that the Brazilian government would have financed the road on its own, and that the road would have been paved at about the same speed. The Bank never examined this assumption. The OED study is emphatic that the Brazilian government would not have been able to pave the road at anything like the same speed without the Bank. It cites the federal government's fiscal crisis in the late 1970s, and the sheer insistence with which the government pressed the Bank for financial help with the road. ${ }^{20}$ Bank support not only speeded up road paving, it also gave the government legitimacy for the whole operation. This in turn boosted the coalition of people who supported the rapid opening of the Northwest, especially the loggers, miners and ranchers, while eclipsing the nebulous opposition to the project within Brazil. "To the eyes of the outside world [...] the financial and technical backing provided by the Bank was generally interpreted as full, institutional subscription to the objectives, basic approach and timing of the program [...] party to a series of actions or inactions by the territorial,

${ }^{19}$ David Knox, who became vice president for Latin America in time for the mid-term review of Polonoroeste, interview, 15 May 1995.

${ }^{20}$ World Bank, "World Bank Approaches to the Environment in Brazil”, vol. V, p. 246. There is no doubt the Brazilian government would have tried to press ahead on its own. The then Minister of the Interior and former Transport Minister aspired to be a presidential candidate. For this purpose he wished to sponsor pharaonic-scale works. He also needed votes from the electoral college. The electoral college was made up of state representatives. Rondônia at the start of the Polonoroeste program was a territory, not a state. Its governor was his brother-in-law, and could assure him Rondônia's electoral college votes if it became a state. Also, the highway program would give the Rondonia government control over federal expenditures within the area, which might be diverted for purposes electoral. But the force of this political argument for paving the highway diminished as the Interior Minister's presidential campaign floundered. 
state and regional administrations that were to have serious adverse environmental consequences in subsequent years" ${ }^{21}$

The Bank failed to act to counter the fundamental asymmetry of commitment. From the beginning, the Brazilian government was much more interested in getting the highway and feeder roads built than in doing the other things that the Bank called for at the same time. The Bank could have conditioned disbursements for the roadworks on progress with the other components. It did not.

\section{POLONOROESTE'S PREDECESSOR: INDONESIAN TRANSMIGRATION PROJECT}

Two of the striking features of Polonoroeste are, first, the way that the cautious assessments of the technical experts in the central, advisory part of the Bank were set aside by regional project staff and regional senior management incentivized by "loan disbursement" as the main metric of career success; second, the use of "the government will do the project anyway, and will do it worse than if the Bank is involved" to justify Bank participation. These features are also evident in the history of a slightly earlier Bank-funded rainforest settlement project, in Indonesia. It is worth taking a quick look to see the similarities.

The Transmigration project, perhaps the most ambitious resettlement scheme in the non-communist world, moved millions of people from Indonesia's crowded inner islands to the thinly populated outer islands. Started on a small-scale in 1950, by the late 1960s it became the top priority project for the Indonesian government. In 1969 Indonesia annexed the western half of New Guinea against local resistance. The government wished to populate the territory with inhabitants from the inner islands so as to bring it reliably under the government's control; and it redoubled its efforts to do the same in the other outer islands, afraid that the Chinese Communists might exploit the presence of overseas Chinese in the outer islands to set up Communist bases, in line with the domino theory. At this time Indonesia, under new leader General Suharto, moved strongly into the western camp, and western states, especially the US, wished to support "our man".

Bank involvement, championed by President Robert McNamara (a believer in the domino theory of Communist expansion), started in 1975, several years before Polonoroeste. Between 1976 and 1986 the Bank lent about \$1 billion. The Bank's money attracted more millions of dollars from other bilateral and multilateral financial agencies; and helped to produce an exponential rise in the rate of

${ }^{21}$ World Bank, "World Bank Approaches to the Environment in Brazil", vol. V, p. 247. 
settlement. In the 15 years after 19763.5 million people were officially resettled, and roughly the same number migrated on their own.

The results were disastrous. A French survey in the late 1980s found that 80 percent of Transmigration sites had failed to improve the living standard of their inhabitants over what it had been before the migration. ${ }^{22}$ A study in 1985 by ministries of the Indonesian government in collaboration with the London-based International Institute for Environment and Development found that the collapse of existing resettlement sites was so common as to pose a problem for national security, as the cities and towns filled with refugees. ${ }^{23}$

From the beginning almost all of the Bank's technical staff - those in the relevant operating division as well as those in the Central Projects Staff and in the World Bank-FAO Cooperative Program - had serious doubts. They worried especially about the capacity of the soils of the outer islands to support intensive settlement. Why had people not migrated long ago from dense Java to the outer islands, if not that the soils of the outer islands were too poor to provide them with alternatives?

Many of the technical staff, though, thought that the FELDA (Malaysia) model of jungle settlement might work. The FELDA model was based on new planting of rubber as a cash crop, together with small plots of mixed fruit and field crops that were intended for subsistence pending maturity of the rubber. It was, however, very expensive.

Then the Bank's project managers learned that McNamara himself had agreed with President Suharto on massive support for a low cost per family program, a cost much lower than the FELDA model, so low as to rule out the planned investment in rubber, leaving annual field crops as the only alternative. The technical staff said this was impossible; field crops would not generate anywhere near enough income. But the Bank's (technically unqualified) line management seized on the results of a small-scale study of field crops in an experimental station, and insisted that these results provided the yield levels to be assumed in the farm model underlying the appraisal report, a blatant falsification.

The central technical personnel protested at this illegitimate extrapolation from carefully controlled experimental station conditions to new farms in felled rainforest, to no avail. One of them later related, "All of us who had a good prac-

\footnotetext{
22 Carolyn Marr, “Uprooting people, destroying cultures: Indonesia's Transmigration program”, Multinational Monitor, October 1990, pp. 12-15.

${ }^{23}$ Government of Indonesia, Department of Forestry, State Ministry of Population, Environment and Development, Department of the Interior, and International Institute for Environment and Development, "A review of policies affecting sustainable development of forest lands in Indonesia", vol. 2, November, 1985, p. 117; and Rich, Mortgaging the Earth, pp. 34-38.
} 
tical knowledge of humid tropical agriculture had no confidence that the high yields obtained under carefully controlled, well managed, experimental station conditions could be replicated under transmigration conditions. Because of my opposition I was thenceforth excluded from the appraisal report, negotiation and Board presentation. Obviously I was aggrieved that my counsel was being rejected, but given the way things were going I was happy to be cleared of any responsibility for a project in which I had little faith. So much for solidly based technical judgments when pressure to lend becomes so important! I firmly believe that the responsibility for sticking so tenaciously with the low cost model could be traced right up to the office of the President [McNamara]. All lower levels of management were unwilling to stand up and be counted. I felt especially sorry for the members of the appraisal team who eventually had to carry this project to the Board. I think it is more than coincidence that [...] the mission leader went down with a heart attack, which I believe was stress related, due to his own reservations about the project and the difficult position in which he found himself [...]A few years after the project went to the Board I happened to meet up with the agronomist who had carried out the field cropping experiments, and when I told him of how his data had been interpreted by the Bank he expressed surprise and incredulity. As for myself, my disgust at the turn of events was such that I decided I wanted out, and I applied for a position at the regional mission in Thailand". ${ }^{24}$

The Transmigration project shows the overwhelming importance of geopolitical considerations in some Bank projects. Once McNamara had made his commitment known (unrelated to technical and economic assessment) the whole line management - the division chiefs and departmental directors in both the project and program hierarchies - worked to justify the project on technical and economic grounds over the strong objections of technical experts. McNamara demanded a cost/benefit justification for everything. So the line management provided him with fraudulent data, derived by illegitimately extrapolating yields on experimental station plots to new jungle farms.

They also developed the argument, "The Indonesians are doing it anyway, they are doing it badly, therefore the Bank should get involved". ${ }^{25}$ Such an argument had not previously been used to justify a Bank project. Its use in the Transmigration case marked a turning point in the organization's history. Once accepted for Transmigration it entered the standard repertoire of justifications, as seen in Po-

\footnotetext{
${ }^{24}$ Bill Panton, personal communication, 4 March 1996.

${ }^{25}$ The director of the Indonesia programs department, Shahid Husain, championed this argument. He was rapidly promoted, and spent twenty years moving around the senior-most management positions in the Bank.
} 
lonoroeste; especially because it could be used to weaken any technical justification for not lending to a project that Bank management wanted in the portfolio for geopolitical or lending target reasons. With technical discipline weakened in practice (though not in appearance), the Bank plunged into a number of projects that the NGOs could later present as debacles.

Did the Polonoroeste project team study the experience of Transmigration? "We had only a vague knowledge of Transmigration", said one of the key people. "No-one ever said, 'We should look at Transmigration". ${ }^{26}$ Learning from other parts of the world was not normal practice in the Bank at this time, despite the existence of the big central pool of project experts.

\section{CONCLUSION}

The Polonoroeste story shows the "street-level" politics behind Susan Park and Antje Vetterlein's generalization: "Change is slow in international bureaucracies such as the IMF and the World Bank because they have organizational cultures or identities through which new norms must penetrate. Change is [...] costly since habits and traditions must be adapted or reinvented [...] Different levels of resistance can be expected according to the organizations' mandate and professional background of staff in relation to different policy fields". ${ }^{27}$

In the Polonoroeste case the main impetus for new norms came from the project leaders themselves, based in the regional programs hierarchy and the regional projects hierarchy, who conceived of the project as the test bed for a new way to do development in rainforests in line with norms of ecological sustainability and indigenous people's protection. The cross-country experts in the central hierarchy championed the same new norms, but argued that the project on the ground, given ecological conditions plus the Brazilian government's lack of capacity, would be unable to deliver the normative objectives.

In Polonoroeste, as also in Indonesia's Transmigration project and many others, the balance of power lay with the operational staff; they could avoid the checks and balances built into the structure without too much difficulty when they had the incentive and when senior management supported them. Since both operational staff and senior managers operated in an incentive structure where their task performance and promotion were judged by their ability to obtain Board approval and disburse the loans, both staff and senior managers often did

\footnotetext{
${ }^{26}$ Denis Mahar, interview, 8 May 1998.

${ }^{27}$ Park and Vetterlein, op. cit., 233.
} 
have an incentive to avoid the checks and balances. The Executive Directors were sometimes only too keen to have the wool pulled over their eyes. Only at the third stage of the Polonoroeste project, by which time evidence lay all around that the first two stages were not working, did some members of the Board express worries; but they were readily reassured by dissembling staff. Not till the mid-term review - when a big NGO campaign against Polonoroeste was underway, and when a new set of Bank staff had taken over the project - did the Board agree to the very unusual step of suspending disbursements until the Brazilian government had made good on (some of) its commitments about ecological and Amerindian protection.

We do not know how many projects were modified, delayed, or cancelled because of internal opposition, and how many sailed through with internal opposition overridden by target-seeking project officers. But we can be sure that the behavior of project managers and the Board in Polonoroeste was not exceptional. This underlines the important role of external monitors - the environmental advocacy NGOs - which in the mid 1980s began to use their leverage with Congress to force the Bank to become more transparent and accountable.

On the other hand, this story also shows that a distinction between project champions inside the Bank and project critics outside the Bank is too simple. The effectiveness of external monitoring, at least in the first years of the normative shift, depended heavily on insiders covertly helping external actors to pressure senior management and their own colleagues.

Partly in response to the Polonoroeste campaign President Barber Conable included the creation of a large environmental complex in the Bank as part of a root-and-branch reorganization in 1986-87. (When James Baker was appointed Treasury Secretary in the second Reagan administration he hatched the plan to protect the US banking system from the risk of a Latin American debt default or restructuring by getting the World Bank to lend heavily to Latin American governments, which would use the money to repay their debts to US banks, thereby shifting the risks of default onto the membership of the World Bank. But the plan required an increase in the US contribution to the capital base of the Bank, and Baker knew that Congress was in no mood to agree, having been roiled up by the environmental NGOs. So Baker took the opportunity to appoint his friend, Barber Conable, an ex-congressman, as the next president, and told him to undertake a big reorganization, including a big push on environmental capacity.) With the creation of a large environmental complex in the Bank, the environmental and indigenous people's protection norms - which had been emerging slowly through the internal and external processes described here - gained Bank-wide "formal validity" by being translated into operational procedures (for example, procedures 
requiring certain types of environmental assessments, certain types of consultations with affected peoples). Ever since then the Bank has been much more wary of sponsoring projects in tropical rainforests, and indeed, more wary of infrastructure projects in general. The Bank's (and other multilateral development banks') pull back from infrastructure left a hole which, much later, China started to fill by leading the creation of the Asian Infrastructure Investment Bank. 